Огляди літератури, оригінальні дослідження, погляд на проблему

удК 616.37-002.2:616-056.527]-008.9--085:[615.356+615.272.4

DOI 10.11603/1811-2471.2016.v0.i4.7093

\title{
ВПЛИВ L-КАРНІТИНУ НА ПРОЯВИ ЛІПІДНОГО ДИСТРЕС-СИНДРОМУ В КОМПЛЕКСНОМУ ЛІКУВАННІ ХРОНІЧНОГО ПАНКРЕАТИТУ У ХВОРИХ НА ОЖИРІННЯ
}

\author{
๑О. С. Хухліна, В. С. Смандич \\ ВДНЗ України «Буковинський державний медичний університет»
}

РЕЗЮМЕ. У роботі представлено вплив L-карнітину на перебіг хронічного панкреатиту у хворих на ожиріння, особливість ліпідного спектра крові, а також ендокринні аспекти його регуляції.

КЛЮчОВІ СЛОВА: хронічний панкреатит, ожиріння, L-карнітин, ліпіди крові.

Вступ. Важливою проблемою в Україні та світі сьогодні $\epsilon$ ожиріння, захворюваність на яке за останні роки зросла на $57 \%$. Це найпоширеніша ендокринна патологія, яка зустрічається, у середньому, в 80 \% ендокринологічних хворих. Серед патології, коморбідної з ожирінням, істотне місце займає хронічний панкреатит (ХП), виникнення якого суттєво знижує якість життя Хворих, сприяє розвитку істотних розладів ліпідного обміну - формуванню ліпідного дистрес-синдрому $[2,7,8]$.

Захворюваність на ХП у хворих з ожирінням складає, за даними різних авторів, від $45 \%$ до $80 \%$ $[3,7,10]$. Розвиток ХП у хворих на ожиріння зумовлений низкою встановлених (зловживання алкоголем, жирами та вуглеводами, нестача в раціоні фруктів, овочів, дефіцит чинників протиоксидантного захисту та протиінфекційного імунітету із наступним розвитком та прогресуванням запального процесу, дистрофічних змін та вільнорадикального пошкодження тканини підшлункової залози тощо) та низкою ще не встановлених факторів, вивчення яких наразі $\epsilon$ дуже актуальним $[2,7,10]$.

Нагальною проблемою сьогодення $\epsilon$ також пошук ефективних засобів корекції фонових метаболічних розладів, які 6 сприяли зростанню ефективності лікування та профілактиці прогресування даних захворювань $[7,8,10]$.

L-карнітин - вітаміноподібна сполука, яка бере участь в процесах обміну речовин в якості переносника жирних кислот через клітинні мембрани з цитоплазми в мітохондрії, де ці кислоти піддаються процесу ß-окислення з утворенням великої кількості метаболічної енергії (у формі АТФ) [1, 4, 5]. L-карнітин нормалізує білковий і жировий обмін, відновлює лужний резерв крові, пригнічує утворення кетокислот і анаеробний гліколіз, зменшує ступінь лактатацидозу, а також підвищує переносимість фізичних навантажень, при цьому сприяє економному витрачанню глікогену і збільшенню його запасів у печінці $[5,6,9,11]$.Доведенапатогенетична роль L-карнітину в лікуванні коморбідного перебігу ожиріння та неалкогольної хвороби печінки [8], цукрового діабету типу 2 із артеріальною гіпертензією [8], при інфаркті міокарда, кардіоміопатіях, серцевій недостатності $[5,6,9,11]$.
Мета дослідження-з'ясувати ймовірний вплив L-карнітину на клінічний перебіг хронічного панкреатиту у хворих на ожиріння, стан ліпідного спектра крові та ендокринні аспекти його регуляції.

Матеріал та методи дослідження. Обстежено 60 хворих на ХП змішаної етіології, больова форма, рецидивуючий перебіг у фазі загострення середньої тяжкості із коморбідним ожирінням I ступеня. Для визначення ефективності лікування за випадковою ознакою було сформовано дві репрезентативні групи пацієнтів. Середній вік хворих становив $(41,7 \pm 4,2)$ років. Контрольну групу склали 30 практично здорових осіб (ПЗО) відповідного віку та статі. Контрольна група (група 1(К) 30 осіб) отримувала гіпокалорійну дієту з усуненням екстрактивних страв, антисекреторний (інгібітор протонової помпи), спазмолітичний (мебеверину гідрохлорид) упродовж 1 місяця, поліферментний (креон 1020 тис. ОД) та гіполіпідемічний (аторвастатин 2040 мг) препарати упродовж 90 днів. Основна група (група 2(О) 30 осіб), крім наведеної вище терапії, отримувала питну форму L-карнітину (стеатель) по 1,0 (10 мл) 2 рази на день упродовж 90 днів.

Аналіз клінічних, ультрасонографічних проявів ХП, біохімічних, лабораторних показників функціонального стану підшлункової залози проводили за загальноприйнятими методиками, які досліджували в динаміці через 15, 30, 90 днів лікування, а також через 3 міс. після лікування. Ліпідний спектр крові визначали за допомогою реактивів фірми “Даниш ЛТД» (м. Львів), вміст у крові лептину визначали за допомогою імуноферментного аналізу (ELISA). Статистичний аналіз результатів дослідження здійснювали за допомогою сучасних методів варіаційної статистики.

Результати й обговорення. Аналіз впливу запропонованої терапії хворим на ХП (група О) на перебіг захворювання у порівнянні із $\mathrm{K}$ групою виявив наступні результати (табл. 1). Покращення самопочуття, зменшення ознак астеновегетативного, інтоксикаційного синдромів, диспептичних проявів у пацієнтів О групи відмічали на 4-5 день від початку лікування, тоді як у хворих К групи лише з 10 дня. Через 2 тижні від початку терапії астеновегетативний синдром значно меншої ін- 
Огляди літератури, оригінальні дослідження, погляд на проблему

Таблиця 1. Характеристика клінічних симптомів хронічного панкреатиту (у балах) у хворих на ожиріння

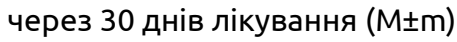

\begin{tabular}{|l|c|c|}
\hline \multicolumn{1}{|c|}{ Клінічний симптом } & \multicolumn{2}{c|}{ Групи хворих } \\
\cline { 2 - 3 } & основна, $\mathrm{n}=30$ & контрольна,n=30 \\
\hline Загальна слабкість (астенія) & $4,6 \pm 0,15^{*}$ & $2,1 \pm 0,21$ \\
\hline Працездатність (фізична, розумова) & $4,8 \pm 0,04^{*}$ & $1,7 \pm 0,03$ \\
\hline Сухість в роті & $4,9 \pm 0,20^{*}$ & $2,4 \pm 0,05$ \\
\hline Нудота & $4,3 \pm 0,11^{*}$ & $1,7 \pm 0,13$ \\
\hline Здуття живота & $4,7 \pm 0,07^{*}$ & $2,8 \pm 0,16$ \\
\hline Більу правій, лівій підреберних ділянках & $4,8 \pm 0,09^{*}$ & $2,5 \pm 0,30$ \\
\hline Відчуття важкості, біль в епігастральній ділянці & $4,7 \pm 0,03^{*}$ & $3,2 \pm 0,14$ \\
\hline Пронос & $3,6 \pm 0,08$ & \\
\hline
\end{tabular}

Примітки: 1. Шкала оцінки: 1 бал - ефект негативний; 2 бали - немає ефекту; 3 бали - задовільно; 4 бали - добре; 5 балів - дуже добре.

2. * - відмінності вірогідні порівняно з групою хворих на ХП контрольної групи $(p<0,05)$.

тенсивності зберігався лише у 3 осіб (10,0\%) О групи, тоді як в К групі він залишався у 11 хворих $(36,7,0 \%)$. У той же термін у більшості хворих О групи зникли біль та відчуття тяжкості в епігастральній ділянці (відповідно у 25 (83,3 \%), а також практично не турбували диспептичні явища (у 28 хворих (93,3 \%), які зберігалися у більшості хворих К групи і на 15, і на 90 день лікування.

Порівняльна динаміка інтенсивності основних клінічних синдромів О та К груп на 30 день лікування виглядала наступним чином: загальні прояви інтоксикаційного синдрому в О групі зменшились на 32-39 \% ( $<20,05)$, порівняно з К групою, прояви диспепсичного синдрому - на 44$65 \%$ (р<0,05), клінічні прояви абомінально-больового синдрому - у межах 41-46\% (p<0,05). Усунення діарейного синдрому під час загострення ХП в обох групах настало одночасно, без суттєвої переваги ефективності курсів лікування.

Аналізуючи показники ліпідного спектра крові (табл. 2) у динаміці лікування обстежених хворих слід вказати на потужні метаболічні, ліпідокоригувальні властивості L-карнітину у відношенні корекції ліпідного дисбалансу у хворих на ХП із ожирінням за відсутності негативного впливу на функціональний стан печінки та підшлункової залози. Хоча у обох групах лікувальний комплекс включав потужний гіполіпідемічний препарат аторвастатин, динамічні показники вмісту ліпідів крові у хворих групи О з включенням L-карнітину були істотно нижчими, ніж показник у хворих K групи, а також вірогідно нижчими, ніж показник до лікування $(p<0,05)$ (див. табл. 2).

Зокрема, Вміст ХС на 30 день лікування у К групі знизився на 13,1\% (p<0,05), у О групі - на 28,4 \%, на 90 день лікування - у К групі - на 26,8 \% ( $<<0,05)$, в О групі - на 34,6 \% ( $p<0,05)$. Слід також зазначити, що вміст у крові ХС після лікування у хворих О групи не лише нормалізувався на 90 день лікування, але й був у межах нормальних показників ще й впродовж 3 місяців після лікування (р>0,05).

Важливим, на нашу думку, аспектом фармакологічних властивостей L-карнітину є його вірогідний вплив на корекцію вмісту ТГ у крові, які, по суті, складають патогенетичну основу стеатозу тканини підшлункової залози за умов ожиріння. L-карнітин можна віднести до класу засобів потужної ліпідкоригувальної, гіполіпідемічної дії, оскільки його призначення привело до оптимізації ліпідного спектра. Доказом цього твердження $\epsilon$ вірогідне зниження вмісту ТГ у крові на 30 день лікування на 30,2 \% у хворих О групи $(p<0,05)$ (див. табл. 2). На противагу цим даним, у К групі зміни вмісту в крові ТГ $є$ менш значними: зниження на $16,4 \%(p<0,05)$. На 90 день лікування показники вмісту у крові ТГ все ще перевищували показник у контролі у всіх групах порівняння: у хворих О групи показник стабільно знизився у 1,8 раза ( $<<0,05)$, а у групі $K$ - у 1,5 раза $(p<0,05)$ та через 3 місяці після лікування знову вірогідно підвищився. Це свідчить про те, що факт корекції вмісту у крові ТГ - це питання часу, яке можливе лише при постійному ретельному призначенні ліпідознижувальної терапії під контролем ліпідограми, корекції дози препаратів та їх оптимальної комбінації.

На 30 день лікування вміст у крові основної фракції проатерогенних ліпопротеїнів (ЛПНЩ) у К групі знизився на 24,0\% (p<0,05), на 90 день лікування зниження склало 39,3 \% ( $<<0,05)$, але нормативного значення показник так і не досяг. У О групі на 30 добу показник знизився у 1,6 раза, на 90 добу - у 1,7 раза $(p<0,05)$ з вірогідною різницею із показниками у групі К. Таке ж співвідношення спостерігалося при аналізі показників через 3 міс. після лікування: вміст ЛПНЩ у О групі зберігався в межах нормативних, а у К групі вірогідно перевищував показник у ПЗО ( $<<0,05)$ і складав підвищену загрозу атерогенезу у цього контингенту осіб. 
Огляди літератури, оригінальні дослідження, погляд на проблему

Таблиця 2. Показники ліпідного спектра крові у хворих на хронічний панкреатит та ожиріння в динаміці

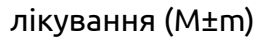

\begin{tabular}{|c|c|c|c|c|c|c|}
\hline Показники & $\Pi 30, n=30$ & Групи & До лікування & Через 30 днів & Через 90 днів & $\begin{array}{c}\text { Через } 3 \text { міс. } \\
\text { після лікування }\end{array}$ \\
\hline \multirow[t]{2}{*}{ ХС, ммоль/л } & \multirow[t]{2}{*}{$4,72 \pm 0,10$} & $\mathrm{~K}$ & $6,93 \pm 0,09$ * & $6,05 \pm 0,12 * / * *$ & $5,07 \pm 0,021 * / * *$ & $6,32 \pm 0,134 * / * *$ \\
\hline & & $\mathrm{O}$ & $6,85 \pm 0,11$ * & $4,94 \pm 0,14 * * / \#$ & $4,51 \pm 0,049 * * / \#$ & $4,76 \pm 0,092$ **/\# \\
\hline \multirow[t]{2}{*}{ ТГ, ммоль/л } & \multirow[t]{2}{*}{$1,47 \pm 0,03$} & $\mathrm{~K}$ & $3,17 \pm 0,01$ * & $2,65 \pm 0,10 * / * *$ & $2,14 \pm 0,026 * / * *$ & $2,45 \pm 0,026 * / * *$ \\
\hline & & 0 & $3,15 \pm 0,01$ * & $2,20 \pm 0,017 * / * * / \#$ & $1,71 \pm 0,025 * / * * / \#$ & $1,83 \pm 0,031 * / * * / \#$ \\
\hline \multirow[t]{2}{*}{ ЛПНЩ, ммоль/л } & \multirow[t]{2}{*}{$2,59 \pm 0,03$} & $\mathrm{~K}$ & $4,58 \pm 0,02$ * & $3,48 \pm 0,045 * / * *$ & $2,87 \pm 0,045 * / * *$ & $3,24 \pm 0,045 * / * *$ \\
\hline & & $\mathrm{O}$ & $4,59 \pm 0,03$ * & $2,83 \pm 0,015 * / * * / \#$ & $2,63 \pm 0,012 * * / \#$ & $2,70 \pm 0,033 * * / \#$ \\
\hline \multirow[t]{2}{*}{ ЛПВЩ, ммоль/л } & \multirow[t]{2}{*}{$1,29 \pm 0,05$} & $K$ & $0,70 \pm 0,01$ * & $0,98 \pm 0,013 * / * *$ & $1,25 \pm 0,010 * *$ & $1,13 \pm 0,017 * / * *$ \\
\hline & & $\mathrm{O}$ & $0,73 \pm 0,01$ * & $1,02 \pm 0,012 * / * *$ & $1,19 \pm 0,015$ ** & $1,11 \pm 0,030 * / * *$ \\
\hline \multirow[t]{2}{*}{ Лептин, мкг/л } & \multirow[t]{2}{*}{$4,61 \pm 0,12$} & $\mathrm{~K}$ & $15,52 \pm 0,41^{*}$ & $14,52 \pm 0,54$ * & $12,40 \pm 0,62$ * & $12,37 \pm 0,59$ * \\
\hline & & 0 & $15,51 \pm 0,42$ * & $12,50 \pm 0,33 * / * *$ & $9,26 \pm 0,47 * / * * / \#$ & $7,23 \pm 0,42 * / * * / \#$ \\
\hline
\end{tabular}

Примітки: 1. *-різниця вірогідна упорівнянніз показникому ПзО (р<0,05); 2. ** - різниця вірогіднау порівнянніз показникомдо лікування (р<0,05); 3. \# - різниця вірогідна у порівнянні з показником після лікування у хворих К групи $(p<0,05)$.

На 30 день лікування вміст у крові основної фракції протиатерогенних ліпопротеїнів - лпвщ у K групі зріс у 1,4 раза $(p<0,05)$, на 90 день лікування -у 1,8 раза $(p<0,05)$, досягши нормативного показника. Заслуга корекції вмісту ЛПВЩ у крові належить статинам - потужним ліпідкоригувальним препаратам. У групі О на 30 добу показник також зріс у 1,4 раза, на 90 добу - у 1,6 раза $(p<0,05)$, досягши нормативних показників, однак вірогідної різниці із показниками у групі К встановлено не було. Таке ж співвідношення спостерігалося при аналізі показників через 3 міс. після лікування: вміст ЛПВГ у К та О групах зберігався в межах, що були нижче нормативних $(p<0,05)$, що також складає підвищений ризик атерогенезу.

Аналогічно змінювався IA, який у хворих О групи вірогідно знижувався на 30 день лікування у межах 1,9 раза $(p<0,05)$, а також при обстеженні на 90 день та через 3 міс. після лікування стабільно досяг нормативних значень. У К групі ІА також знижувався під впливом лікування (у 1,6 раза $(p<0,05))$, однак норми не досяг.

Ультрасонографічне дослідження підшлункової залози після лікування хворих на ХП О групи виявило істотне зниження ступеня стеатозу (зменшення відсотка дорзального згасання ехосигналу), трансформацію середньозернистої структури па- ренхіми у дрібнозернисту та більш однорідну, а також зменшення запального набряку підшлункової залози (вертикальний розмір головки $(26,0 \pm 2,3) \mathrm{Mм}$ проти $(34,3 \pm 3,2)$ мм до лікування, $(p<0,05))$, тоді як через 3 міс. після лікування даний параметр вже становив $(23,0 \pm 2,1)$ мм $(27,8 \%(p<0,05))$. Нами також був проаналізований інтегральний біохімічний показник, який відображає ступінь регуляції ліпідного обміну - вміст у крові лептину - гормону жирової тканини, який у хворих О групи вірогідно знижувався на 90 день лікування на 40,0\% $(p<0,05)$, а також при обстеженні через 3 міс. після лікування - знизився на 53,1 \% (див. табл. 2). У К групі вміст лептину також знижувався під впливом лікування, але невірогідно ( $>>0,05)$.

Висновок. Застосування L-карнітину у комплексній терапії хворих на ХП із ожирінням сприяє швидшому досягненню клінічної ремісії ХП, оптимізації ліпідного спектра крові, зменшенню ступеня стеатозу та запального набряку підшлункової залози, потенціюванню дії статинів, а також нормалізації процесів регулювання ліпідного обміну у хворих на ожиріння.

Перспективою подальших досліджень у цьому напрямку $\epsilon$ дослідження інших метаболічних ефектів L-карнітину у хворих із коморбідним перебігом хронічного панкреатиту та ожиріння.

\section{ЛІТЕРАТУРА}

1. Асташкин Е. И. Роль L-карнитина в энергетическом обмене кардиомиоцитов и лечении заболеваний сердечно-сосудистой системы / Е. И. Асташкин, М. Г. Глезер // Кардиология и сердечно-сосуд. хир. 2012. - № 2. - С. 58-65.

2. Бондаренко О. А. Клиническая диагностика хронического панкреатита в сочетании с ожирением / О. А. Бондаренко //Укр. тер. журнал. - 2012. - № 3-4. - С. 35-39.
3. Клюйко Д. А. Сравнение эффективности антиоксидантных препаратов применительно к острому панкреатиту в эксперименте / Д. А. Клюйко, В. Е. Корик, С. А. Жидков// Эксперимент. и клин. фармакология. 2011. - № 9. - С. 11-15.

4. Леонтьева И. В. Значение метаболических нарушений в генезе кардиомиопатий и возможности применения L-карнитина для терапевтической коррекции / 
Огляди літератури, оригінальні дослідження, погляд на проблему

И. В. Леонтьева, В. С. Сухоруков // Вестник педиатр. фармакол. и нутрициол. - 2006. - № 2. - С. 12-14.

5. Опыт применения инфузионного отечественного препарата левокарнитина при синдроме малого выброса у больных острым инфарктом миокарда / Н. Ю. Семиголовский, Е. К. Верцинский, Б. А. Азанов [и др.]//Бюл. НЦССХим.А.Н.Бакулева РАМН.-2012.-№3.C. 69 .

6. Первый клинический опыт применения инфузионного отечественного препарата левокарнитина при синдроме малого выброса у больных инфарктом миокарда, тромбоэмболией легочной артерии и дилатационной кардиомиопатией / Н. Ю. Семиголовский, Е. К. Верцинский, Б. А. Азанов [и др.] // Материалы 6-го съезда ассоциации анестезиологов-реаниматологов Северо-Запада России // Эфферентная тер. - 2011. № 3. - С. 136-137.

7. Сосудистые заболевания поджелудочной железы и сосудистые осложнения панкреатической патологии: лучевые, сонографические и морфологиче- ские сопоставления (обзор литературы) / Н. В. Момот, Н. Б. Губергриц, Ю. А. Загоренко [и др.] // Мед. визуализация. - 2005. - № 5. - С. 11-21.

8. Хухліна О. С. Неалкогольний стеатогепатит та гіпертонічна хвороба: особливості коморбідного перебігу, оптимізовані підходи до лікування / О. С. Хухліна, О. Є. Мандрик. - Чернівці, 2014. - 203 с.

9. Элькар (левокарнитин): возможность срочной энергетической коррекции нарушений метаболизма в головном мозге при острой цереброваскулярной патологи / В. А. Жуков, Л. Э. Ельчинская, А. В. Леонтьева [и др.] // Врач скорой помощи. - 2011. - № 2. - С. 41-46.

10. Денисова Т. П. Клинико-эпидемиологические аспекты течения острого панкреатита в последнем десятилетии XX века / Т. П. Денисова, Л. А.Тюльтяева // Казанский мед. журнал. - 2009. - Т. 90, № 6. - С. 897-900.

11. Metabolic treatment with L-carnitine in acuteanterior ST segment elevation myocardialinfarction. A randomized controlled trial / G. Tarantini, D. Scrutinio, P. Bruzzi [et al.] // Cardiology. - 2006. - Vol. 106, № 4. - P. 215-223.

\title{
EFFECT OF L-CARNITINE ON THE MANIFESTATIONS OF LIPID DISTREES SYNDROME IN TREATMENT OF CHRONIC PANCREATITIS IN PATIENTS WITH OBESITY
}

๑O. S. Khukhlina, V. S. Smandych

\author{
Bukovynian State Medical University
}

SUMMARY. In this paper, the effects of L-carnitine on the course of chronic pancreatitis in patients with obesity, blood lipid spectrum feature and endocrine aspects of its regulation, are presented.

KEY WORDS: chronic pancreatitis, obesity, L-carnitine, blood lipids. 